\title{
KlasifikasiAnalisis Sentimen Pada Gambar Meme Politik Dengan Library Tesseract Dan Algoritme Support Vector Machine
}

\author{
Eko Sanjaya $^{1)}$, Agi Prasetiadi ${ }^{2)}$ Wahyu Andi Saputra ${ }^{3)}$ \\ ${ }^{1,2,3)}$ Program Studi Teknik Informatika, Fakultas Teknik Industri dan Informatika, \\ Institut Teknologi Telkom Purwokerto \\ Jl. D.IPanjaitan, No 128, Karangreja, Purwokerto Kidul, Kabupaten Banyumas, Jawa Tengah
}

Accepted on 12-08-2019

\begin{abstract}
Meme merupakan penyebaran informasi dalam bentuk gambar. Berdasarkan data yang diperoleh, pengembangan meme mulai meningkat menjelang pemilu 2019. Informasi yang diperoleh dari meme politik beragam. Salah satunya memberikan dukungan untuk suatu partai atau tokoh politik atau digunakan untuk mengkritik / mencaci-maki partai politik atau tokoh. Sehingga diperlukan suatu sistem yang dapat mengklasifikasikan meme berdasarkan kelas Penelitian ini bertujuan untuk menciptakan sistem yang dapat mengklasifikasikan meme politik berdasarkan kelas. Algoritma yang akan digunakan dalam mengklasifikasikan adalah Support vector macine (SVM) dengan ekstraksi fitur TF-IDF. Library yang akan digunakan dalam optical character recognition (OCR) adalah Tesseract. Berdasarkan hasil pengujian diketahui bahwa akurasi yang dihasilkan oleh SVM linier lebih baik daripada SVM non-linear. Akurasi terbaik dalam SVM linear dengan kombinasi TF-IDF adalah $75.71 \%$.
\end{abstract}

Kata Kunci: Analisis sentimen, Meme politik, Ocrtesseract, Support Vector Machine

\section{INTRODUCTION}

$\mathbf{P}$ rkembangan teknologi dan informasi yang sangat pesat, memudahkan masyarakat berkomunikasi dengan yang lainnya. Perkembangan teknologi informasi ini, tidak luput dari perkembangan internet yang terus meningkat. Adanya internet, setiap manusia memiliki akses untuk dapat mencari dan memberikan informasi yang dibutuhkan. Dalam penyebaran informasi di social media mulai beragam, salah satunya menyebarkan informasi dalam bentuk teks gambar yang juga disebut meme. Istilah meme pertama kali dipopulerkan oleh Richard Dawkins dalam bukunya The Selfish Gene(1976). Menurut pemahaman Dawkins, meme adalah bentuk dari gen kebudayaan (ide, gagasan, pola perilaku, dan sebagainya) yang menyebar melalui proses imitasi, seperti halnya lagu, jargon, mode pakaian, hingga cara membangun gedung[1].

Penyampain informasi menggunakan meme mulai popular dikalangan masyarakat dalam belakangan ini. Kepopuleran tersebut ditunjukan dengan adanya website-website meme seperti 1cak.com dan memecomic.id. Dengan adanya website tersebut masyarat sering menggunakan meme di akun sosial media. Meme dapat dikategorikan menjadi dua[2], pertama meme ringan seperti meme candaan, motivasi, dan olahraga. Sedangkan meme kedua adalah meme yang berat seperti membahas pemerintahan dan politik. Kelebihan meme dalam penyampain informasi adalah menambahkan daya tarik masyarakat dalam membaca dan dapat mempermudah dalam menangkap informasi. Sekarang ini meme berat mulai sering digunakan oleh pendukung suatu partai politik untuk mendukung suatu partai atau tokoh politik yang didukung ataupun digunakan untuk mengkritik/ mencaci-makisuatu partai politik lain atau tokoh lain karena rasa ketidaksukaannya. 
Dalam penggalian data dapat menggunakan Text Mining. Dengan menggunakan Text Mining, peneliti mendapatkan informasi yang berguna dan dapat meningkatkan pengetahuan bagi peneliti. Text mining dapat diterapkan dalam beberapa bidang, salah satunya adalah Analisis Sentimen. Analisis sentimen adalah bidang studi yang menganalisis pendapat seseorang, sentimen seseorang, evaluasi seseorang, sikap seseorang dan emosi seseorang ke dalam bahasa tertulis[3].

Text Mining juga dapat berfungsi sebagai klasifikasi, yang prosesnya untuk menemukan model untuk menggambarkan class atau konsep dari suatu data, dan juga digunakan untuk mendiskripsikan data penting serta dapat menprediksi data pada masa depan. Pada penelitian ini, data yang akan dianalisis adalah data berupa text yang diambil dari gambar meme yang didapatkan dari media sosial, khususnya meme mengenai politik.

Proses klasifikasi meme dapat dilakukan dengan menggunakan Library Tesseract untuk mengubah teks gambar/meme menjadi teks digital dan algoritma Support vector machine (SVM) digunakan untuk mengklasifikasi teks menjadi tigas kelas yaitu, kelas meme positif, kelas meme netral dan kelas positif. Tujuan dari penelitian ini adalah mendapatkan nilai akurasi menggunakan LibraryTesseract danAlgoritmeSupport Vector Machine (SVM).

\section{II.RESEARCH METHOD}

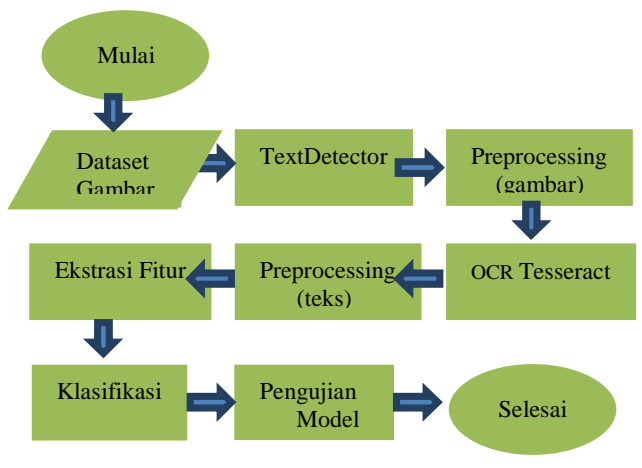

Gambar 1. Tahapan Penelitian

\section{A. Pengumpulan Dataset}

Pada tahap ini pengumpulan dataset didapatkan dari postingan atau komentar di social media (Facebook, instagram dan twitter). Gambar yang diambil memiliki ketentuan seperti gambar minimal berkurang 320x320 pixel, teks mudah dibaca oleh system, background dari karakter harus kontras atau tidak memiliki background. Dataset yang digunakan dalam penelitian ini adalah 444 gambar meme dan diambil 31 sampel gambar meme secara random untuk dilakukan pengujian data baru.

\section{B. TextDetector}

Textdetector adalah menentukan suatu keberadaan objek (teks) dan ruang lingkupnya serta lokasi didalam sebuah gambar[4]. Tahapan text detector dalam penelitian ini menggunakan penelitian yang telah dilakukan oleh Zhou Xinyu dkk yaitu system EAST: An Enfficient and Accurate Text Detector[5]. Text detector EAST memiliki kelemahan tidak dapat memotong teks secara sempurna, Sehingga penulis memodifikasi system EAST agar dapat memotong teks dengan sempurna. 


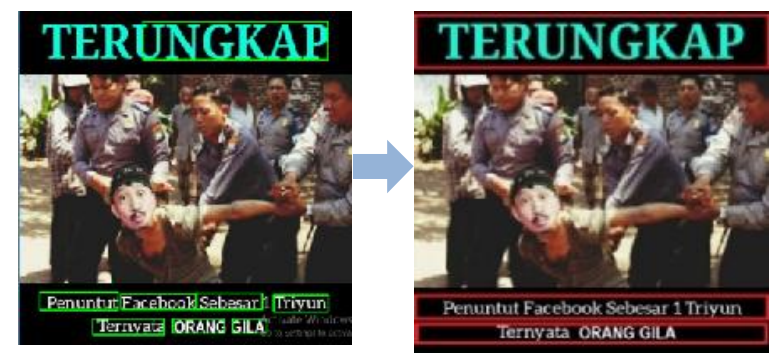

Gambar 2. Text Detector

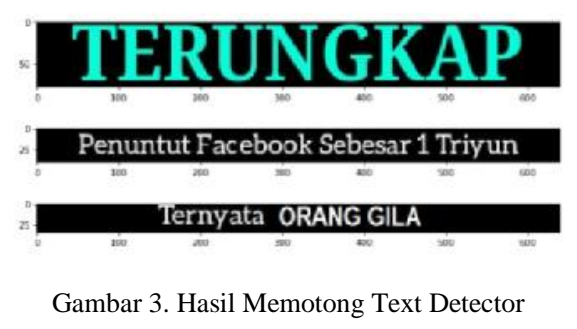

\section{Preprocessing (Gambar)}

Preprocessing pada gambar menjadi salah satu tahapan terpenting yang bertujuan untuk menghilangkan noise dan menyederhanakan gambar agar mudah dikelola saat tahap OCR tesseract. Preprocessing pada gambar terdiri lima tahap, yaitu:

1. Grayscale: menyederhanakan gambar.

2. Blur: mengurangi noise dan mengurangi detail.

3. Threshold: mengatur jumlah derajat keabuan pada citra.

4. Erosion: mengikis batas-batas tepi objek dan menghapus semua pixel yang dekat dengan batas. Sehingga erosion dapat menghilang/menghapus noise kecil.

5. Dilation: mempertebal font yang telah dikikis oleh tahap erosion dan dapat meningkat ukuran teks sehingga dapat mempermudah dalam pengenalan karakter.

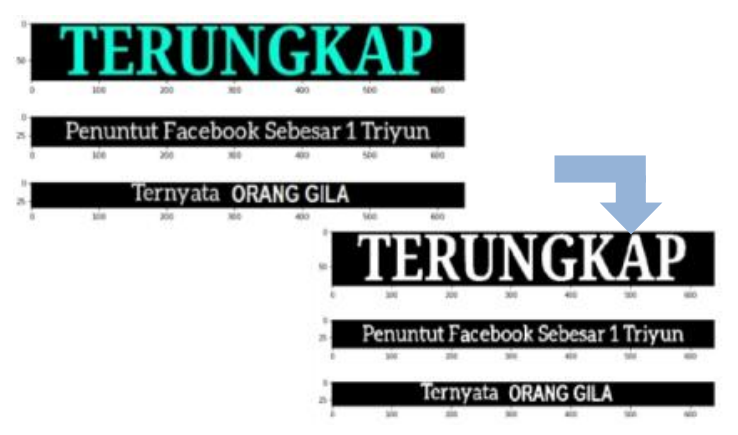

Gambar 4. HasilPreprocessing Pada Gambar

\section{OCR Tesseract}

OCR tesseract adalah tahapan mengekstrak teks didalam gambar menjadi teks digital dengan menggunakan library tesseract dengan akurasi tinggi. Tesseract dikembangkan sebagai perangkat lunak berpemilik oleh Hewlett Packard Labs. Pada tahun 2005, itu terbuka bersumber dari HP bekerja sama dengan University of Nevada, Las Vegas. Sejak 2006 telah dikembangkan secara aktif oleh Google dan banyak kontributor open source[6]. 


\section{TERUNGKAP \\ Terdetekksi: TERUNGKAP}

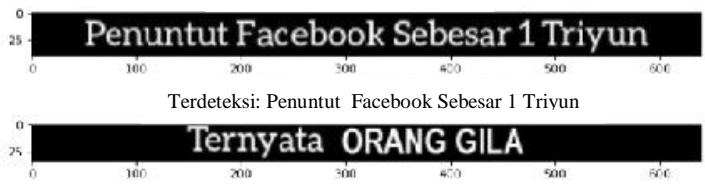

Terdetekksi:Ternvata ORANG GILA

Gambar 5. Hasil OCR Tesseract

\section{E. Preprocessing (Teks)}

Preprocessing pada teks adalah tahapan memperbaiki teks hasil OCR tesseract yang belum sempurna dan juga berguna untuk mempersiapkan data teks menjadi lebih struktur. Tahapan preprocessing pada teks terdiri lima, yaitu:

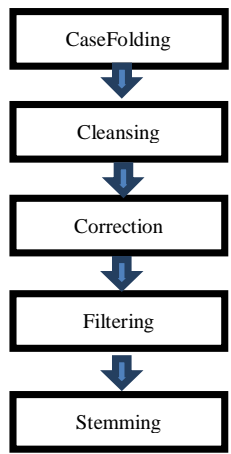

Gambar 6. Tahapan Preprocessing

1. CaseFolding:merubahkarater menjadi bentuk standard(uppercase ataulowercase).

2. Cleansing: menghapus karakter seperti symbol, tanda Tanya dan angka.

3. Correction: memperbaiki ejaan yang tidak sesuai dengan KBBI tapi dapat diperbaiki dan menghapus ejaan yang tidak sesuai dengan KBBI atau benar-benar tidak dapat diperbaiki akan dihapus[7].

4. Filtering: membuang kata yang tidak memiliki arti atau kata yang sering muncul seperti kata "dari”, "dan", "yang” dan lain-lain.

5. Stemming: mengubah kata berimbuhan menjadi kata dasar sesuai dengan kamus KBBI. System kerja dari stemming adalah menghapus awalan kata(prefiks), akhiran(sufliks) dan gabungan awalan dan akhiran(konflik)[8].

TABEL I

PREPROCESSING TEKS

\begin{tabular}{|c|l|l|}
\hline No & \multicolumn{1}{|c|}{ Proses } & \multicolumn{1}{c|}{ Hasil } \\
\hline 1 & Teksasli & $\begin{array}{l}\text { TERUNGKAP Penuntut Facebook Sebesar 1 TrivunTernyata } \\
\text { ORANG GILA }\end{array}$ \\
\hline 2 & Casefolding & terungkappenuntutfacebooksebesar 1 trivunternyata orang gila \\
\hline 3 & Cleansing & terungkappenuntutfacebooksebesartrivunternyata orang gila \\
\hline 4 & Correction & terungkappenuntutsebesartriliunternyata orang gila \\
\hline 5 & Filtering & terungkappenuntuttriliun orang gila \\
\hline 6 & Stemming & ungkaptuntuttriliun orang gila \\
\hline
\end{tabular}




\section{F. Ekstraksi Fitur}

Ekstraksi fitur yang digunakan adalah metode Term Frequency Term Frequency Inverse Document Frequency (TF-IDF). Metode TF-IDF adalah metode untuk menghitung bobot setiap kata yang paling umum digunakan pada informasi retrival[9]. Metode TF-IDF merupakan perhitungan Term frequency (TF) dengan Inverse Document Frequency (IDF) pada tiap term disetiap dokumen dalm korpus. Berikut merupakan rumus dari persamaan TF-IDF.

$$
W d t=T F d t \times I D F t
$$

Invers document frequency (IDF) menunjukkanketersediaansebuah kata (term) dalamseluruhdokumen. Semakinsedikitdokumenmengandung term makasemakinbesarnilai IDF.

$$
I D F t=\log \left(\frac{D}{d f}\right)
$$

Dimana:

D adalah total dokumen

dfadalahbanyakdokumen yang mengandung term

TF adalahjumlahataufrekuensikemunculan term $t$ dalamdokumen $d$

$\mathrm{W}$ adalahbobotdokumenke- $d$ terhadap kata term ke- $t$

\section{G. Klasifikasi}

Tahapan klasifikasi menggunakan algoritmesupportvectormachine. Algoritma support vector machine dibagi menjadi dua yaitu support vector machineliniear dan supportvectornon-linear.

\section{1) Support VectorMachine}

Support vector machine adalah suatu teknik untuk prediksi, baik dalam kasus klasifikasi maupun regresi. Algoritma ini masuk kelas supervised learning dimana dalam implementasinya perlu adanya tahap training menggunakan sequential training kemudian disusul tahap testing[10].Konsep support vector machine (SVM) adalah membentuk hyperplane terbaik yang berfungsi untuk memisahkan dua kelas atau lebih. Hyperplane merupakan garis atain bilang datar yang memiliki tujuan untuk memisahkan dua kelas data.

$$
\text { Hyperplane } \quad \overrightarrow{\mathrm{H}} \cdot \overrightarrow{\mathrm{H}} \overrightarrow{\mathrm{H}}+b=0
$$

Data kelas negative dan kelas positif dapat dirmimsan sebagai berikut:

$$
\begin{aligned}
& \text { Kelas negatif } \quad \overrightarrow{\text { III. }} \cdot \vec{H}+b \leq-1 \\
& \text { Kelas positif } \quad \overrightarrow{\text { III }} \text {. } \vec{H} \vec{H}+b \geq+1
\end{aligned}
$$

Persamaan Support vector machine sebagai berikut:

$$
f(x)=w \cdot x+b
$$

Atau

$$
f(x)=\sum_{i=1}^{m} \propto_{i} y_{i} K\left(x_{i}, x_{j}\right)+b
$$

\section{Dimana:}

w adalah Parameter Hyperplane yang dicari

$\mathrm{x}$ adalah nilai masukan atribut

$\mathrm{b}$ adalah nilai bias 

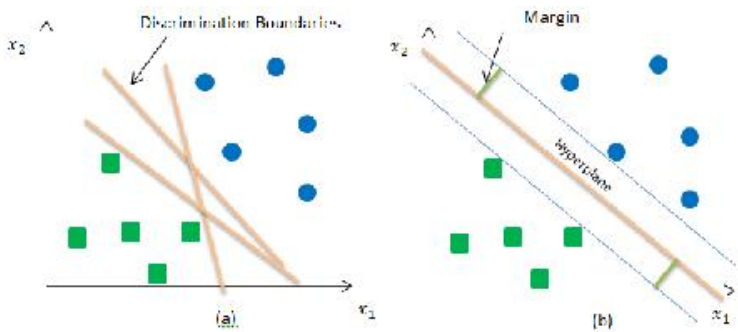

Gambar 6. (A) Gambar HyperplaneYang MungkinDan (B) Gambar HyperplaneDengan Margin Terbaik

\section{2) Support Vector MachineNon-linear\&Kernel Trick}

Pada dasarnya masalah di dunia nyata (real world problem) jarang bersifat linear separable dan umumnya masalah bersifat non-linear. SVM dimodifikasi dengan memasukan fungsi kernel. Dalam SVM non-linear, pertama data $(\mathrm{x})$ akan naikan ruang vector menjadi berdimensi lebih tinggi dengan fungsi $(\mathrm{x})[11]$.

$$
\phi\left(x_{i, j}\right)=\phi\left(x_{i}\right) \cdot \phi\left(x_{j}\right)
$$

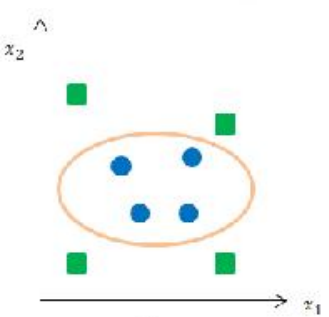

(a)

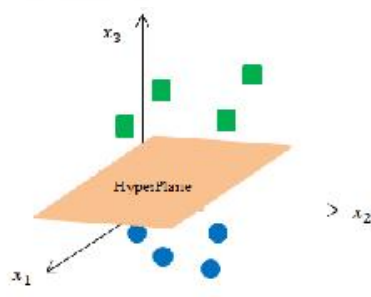

(b)

Gambar 7. Fungsi (X)Memetakan Data Ke Ruang Vector Yang Berdimensi Lebih Tinggi

\section{3) Pengujian}

Pengujian dilakukan dua tahap yaitu pengujian pada model dan pengujian pada sampel baru. Pengujian model menggunakan K-Fold Cross Validation dan pengujian pada sampel baru menggunakan Confusionmatrix.K-Fold Cross Validation adalah teknik validasi dengan membagi data secara acak kedalam $\mathrm{K}$ bagian dan masing-masing akan dilakukan proses klasifikasi[12].

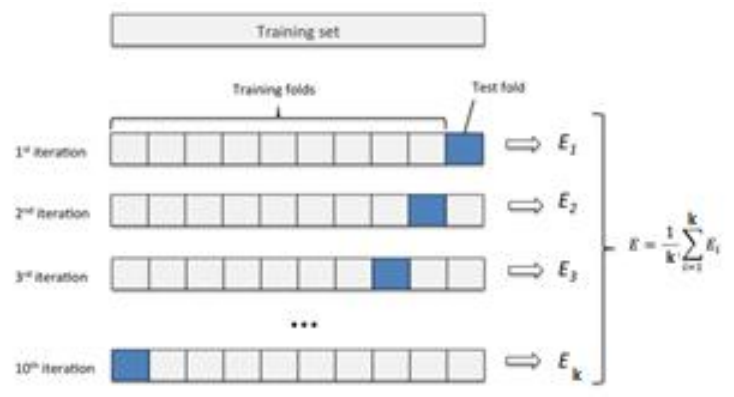

Gambar 8. K-Fold Cross Vallidation

Confusion matrix merupakan sebuah metode yang biasa digunakan untuk melakukan pengukuran pada suatu classifier dalam melakukan prediksi dari kelas yang berbeda[13]. 
TABEL II

CONFUSION MATRIX (3X3)

\begin{tabular}{|c|c|c|c|c|}
\hline \multicolumn{2}{|c|}{ Confusion Matrix } & \multicolumn{3}{c|}{ NilaiPrediksi } \\
\cline { 2 - 5 } & A & B & C \\
\hline \multirow{2}{*}{$\begin{array}{c}\text { NilaiSebenar } \\
\text { nya }\end{array}$} & A & AA & AB & AC \\
\cline { 2 - 5 } & B & BA & BB & BC \\
\cline { 2 - 5 } & C & CA & CB & CC \\
\hline
\end{tabular}

Akurasi $=\frac{A A+B B+C C}{A A+A B+A C+B A+B B+B C+C A+C B+C C} \times 100 \%$

Presisi $=\frac{A i}{A i+B i+C i} \times 100 \%$

Recall $=\frac{i A}{i A+i B+i C} \times 100 \%$

\section{RESULTS AND DISCUSSION}

Hasil penelitian didapatkan dari pengujian akurasi OCR Tesseract, pengujian model SVM linear dan non-linear, dan pengujian pada data gambar meme baru.

\section{A. Pengujian Model SVM Linear Dan Non-Linear}

Setelah model selesai dibuat, tahap selanjutnya dilakukan pengujian pada model SVM menggunakan metode K-Fold Cross Validation.

TABEL III

HASIL K-FOLD VALIDATION

\begin{tabular}{|c|c|c|c|c|}
\hline \multirow{2}{*}{ No } & \multicolumn{4}{|c|}{ SVM } \\
\cline { 2 - 5 } & Linear & RBF & Polynomial & Sigmoid \\
\hline 1 & $80.95 \%$ & $69.05 \%$ & $69.05 \%$ & $69.05 \%$ \\
\hline 2 & $76.19 \%$ & $69.05 \%$ & $69.05 \%$ & $69.05 \%$ \\
\hline 3 & $83.33 \%$ & $78.57 \%$ & $78.57 \%$ & $78.57 \%$ \\
\hline 4 & $76.19 \%$ & $73.81 \%$ & $73.81 \%$ & $73.81 \%$ \\
\hline 5 & $73.81 \%$ & $73.81 \%$ & $73.81 \%$ & $73.81 \%$ \\
\hline 6 & $71.43 \%$ & $71.43 \%$ & $71.43 \%$ & $71.43 \%$ \\
\hline 7 & $66.67 \%$ & $66.67 \%$ & $66.67 \%$ & $66.67 \%$ \\
\hline 8 & $71.43 \%$ & $66.67 \%$ & $66.67 \%$ & $66.67 \%$ \\
\hline 9 & $78.57 \%$ & $71.43 \%$ & $71.43 \%$ & $71.43 \%$ \\
\hline 10 & $80.95 \%$ & $71.43 \%$ & $71.43 \%$ & $71.43 \%$ \\
\hline Mean & $75.95 \%$ & $71.19 \%$ & $71.19 \%$ & $71.19 \%$ \\
\hline
\end{tabular}

Pengujian akurasi model corpus dilakukan beberapa kategori yang bertujuan untuk mendapatkan model corpus dengan akurasi terbaik. Model corpus terbaik akan digunakan untuk melakukan prediksi pada data uji baru. Berdasarkan Tabel diatas bahwa model SVM Linear menggunakan ekstrasi fitur TFIDF memiliki akurasi terbaik.

\section{B. Pengujian Pada Data Gambar Meme Baru}

Setelah didapatkan model dengan akurasi terbaik, selanjutnya mengimplementasikan model untuk menguji gambar meme baru. Meme yang akan diujikan sebanyak 31 gambar berdasarkan Control Limit Theorm. Metode yang digunakan dalam pengujian gambar meme baru adalah Confusion Matrix. 
TABEL IV

Hasil Pengujian Model Pada Gambar Meme Baru

\begin{tabular}{|c|c|c|c|c|}
\hline \multirow{2}{*}{ Confusion Matrix } & \multicolumn{3}{c|}{ NilaiPrediksi } \\
\cline { 2 - 5 } & Negatif & Netral & Positif \\
\hline \multirow{3}{*}{$\begin{array}{c}\text { NilaiSebenar } \\
\text { nya }\end{array}$} & Negatif & 17 & 1 & 1 \\
\cline { 2 - 5 } & Netral & 2 & 2 & 1 \\
\cline { 2 - 5 } & Positif & 4 & 1 & 2 \\
\hline
\end{tabular}

TABELV

Hasil Pengujian Model Pada Gambar Meme Baru

\begin{tabular}{|c|c|c|}
\hline \multirow{2}{*}{ Klasifikasi } & \multicolumn{2}{|c|}{ Support Vector Machine } \\
\cline { 2 - 3 } & Precision & Recall \\
\hline Negatif & $74.00 \%$ & $89.00 \%$ \\
\hline Netral & $50.00 \%$ & $40.00 \%$ \\
\hline Positif & $50.00 \%$ & $29.00 \%$ \\
\hline
\end{tabular}

TABELVI

Hasil AKurasi Model Pada Gambar MEme Baru

\begin{tabular}{|c|c|c|}
\hline Algoritma & Ekstraksi Fitur & Akurasi \\
\hline SVM Liniear & TF-IDF & $67.74 \%$ \\
\hline
\end{tabular}

Meme politik dapat dikategorikan kelas positif, jika teks didalam meme politik memiliki atribut dengan nilai bobot term yang sesuai dengan nilai bobot term di data training dan meme politik memasuki ke ruang kelas positif maka hasil meme politik tersebut akan diprediksi sebagai kelas positif. Hal itu juga berlaku pada kelas yang lain.

Suatu meme politik yang diprediksi tidak sesuai dengan kelas sebenarnya. Hal ini dikarenakan terdapat beberapa faktor yaitu, Pertama hasil dari OCR Tesseract tidak sesuai dengan teks di dalam gambar meme sehingga dalam pembobotan term tidak memiliki nilai bobot sebenarnya. Kedua terdapat kata baru yang belum ada di data training dan tidak memiliki nilai bobot term dan tidak memiliki nilai atribut yang sesuai, sehingga meme politik tersebut dapat dekat dengan kelas yang lain dan juga meme politik tersebut dapat melewati Hyperplane yang dimana dapat memasuki kelas lain.

\section{CONCLUSION}

Berdasarkan hasil penelitian yang telah dilakukan bahwa SVM dengan kernel Linear memiliki akurasi 75.95\%, sedangkan SVM Non-Linear(dengan kernel RBF, Polynomial dan Sigmoid) memiliki akurasi 71.19\%. Berdasarkan hasil akurasi setiap kernel dapat disimpulkan bahwa SVM Linear memiliki akurasi lebih baik daripada SVM Non-Linear dalam melakukan pengklasifikasi meme politik. Berdasarkan hasil pengujian data baru memememiliki akurasi rendah yaitu $67.74 \%$. Hal ini terjadi dikarenakan jumlah data training negatif lebih banyak daripada data training yang lain. Jadi atribut pada data baru lebih condong ke kelas negatif.

Penelitian selanjutnya, diharapakan menggunakan metode lain dalam optical character recognition (OCR), menambahkan fitur object detector yang lain seperti face detector, Menggunakan ekstraksi fitur lain seperti convert negation atau unigram dan menggunakan algoritma klasifikasi lain seperti naïve bayes, decisiontree, K-NN atau neuralnetwork. 


\section{ACKNOWLEDGEMENT}

TerimakasihkepadaAgiPrasetiadi, S.T., M.Engdan Wahyu Andi Saputra, S.Pd.,M.Engselakudosenpembimbing yang senantiasadalammembimbinglaporanjurnal.

\section{REFERENCES}

[1] R. Dawkins, "The Selfish Gene," Oxford Univ. Press, 1976

[2] F. Haisar, "Klasifikasi Analisis Sentimen Meme Dengan Metode Optical Character Recognition ( OCR ) dan Algoritma Naive Bayes," Pengemb. Teknol. Inf. dan Ilmu Komput., vol. 2, no. 8, 2018.

[3] S. Fanissa, M. A. Fauzi, and S. Adinugroho, "Analisis Sentimen Pariwisata di Kota Malang Menggunakan Metode Naive Bayes dan Seleksi Fitur Query Expansion Ranking,” Pengemb. Teknol. Inf. dan Ilmu Komput., vol. 2, no. 8, pp. 2766-2770, 2018

[4] F. Jallad, "Object Detection Using Image Processing," Moscow Inst. Phys. Technol. Dep. Radio Eng. Cybern., vol. 1, no. 1, pp. 1-6, 2016

[5] X. Zhou, C. Yao, H. Wen, Y. Wang, S. Zhou, W. He, and J. Liang, "EAST : An Efficient and Accurate Scene Text Detector," Comput. Vis. Found., vol. 1, no. 1, pp. 1-10, 2015.

[6] V. S. CHANDEL, "Deep Learning based Text Recognition (OCR) using Tesseract and OpenCV," 2018. [Online]. Available: https://www.learnopencv.com/deep-learning-based-text-recognition-ocr-using-tesseract-and-opencv/. [Accessed: 28-Dec2018].

[7] H. Sujaini and R. D. Nyoto, "Analisis Perbadingan Metode spelling Corrector Peter Norvig dan Spelling Checker BK-Trees pada kata berbahasa indonesia,” J. Sist. dan Teknol. Inf., vol. 5, no. 1, pp. 1-5, 2016.

[8] L. Agusta, "Perbadingan Algoritma Stemming Poter dengan Algoritma Nazief-Adriani untuk Stemming Dokumen Teks Bahasa Indonesia," in Konferensi Nasional Sistem dan Informatika, 2009, pp. 196-201.

[9] M. Fitri, "perancangan Sistem Temu balik informasi dengan Metode Pembobotan Kombinasi TF-IDF untuk pencarian Dokumen berbahasa indonesia," Teknol. Inf. dan Komun., vol. 1, no. 1, pp. 1-6, 2018.

[10] R. S. Perdana and M. A. Fauzi, "Analisis Sentimen Tingkat Kepuasan Pengguna Penyedia Layanan Telekomunikasi Seluler Indonesia Pada Twitter Dengan Metode Support vector machine dan Lexicon Based Features," Pengemb. Teknol. Inf. dan Ilmu Komput., vol. 1, no. 12, pp. 1725-1732, 2017.

[11] S. R. Kurniasari, "Implementasi SVM dan Asosiasi untuk Sentiment Analysis Data Ulasan The Phoenix Hotel Yogyakarta pada Situs Tripadvisor," 2018

[12] S. E. Lidya, Syahfitri Kartika, Opim Salim Sitompul, "SENTIMENT ANALYSIS PADA TEKS BAHASA INDONESIA MENGGUNAKAN SUPPORT VECTOR MACHINE ( SVM )," Teknol. Inf. dan Komun., vol. 2015, no. Sentika, pp. 1-8, 2015.

[13] M. F. Fibrianda and A. Bhawiyuga, “Analisis Perbandingan Akurasi Deteksi Serangan Pada Jaringan Komputer Dengan Metode Naïve Bayes Dan Support vector machine ( SVM )," Pengemb. Teknol. Inf. dan Ilmu Komput., vol. 2, no. 9, pp. $3112-3123,2018$ 